\title{
ELEMENTOS DO RITMO LENTO DA TERRITORIALIZAÇÃO DO AGROARTESANATO FAMILIAR EM FRANCISCO BELTRÃO/PR
}

\section{Elements of the slow rhythm of the territorial action of the craft rural and familiar industry in Francisco Beltrão/PR}

\author{
Márcio Freitas Eduardo ${ }^{1}$ \\ Marcos Aurelio Saquet ${ }^{2}$
}

\section{RESUMO}

Neste texto, revelamos alguns resultados de nossa pesquisa sobre a dinâmica territorial existente em unidades produtivas familiares que produzem alimentos por meio da transformação por técnicas e tecnologias rudimentares e do trabalho familiar no município de Francisco Beltrão (PR). Esta produção resulta de um processo histórico e territorial específico, marcado pela colonização realizada no Sudoeste do Paraná por descendentes de alemães, poloneses e italianos provenientes do Rio Grande do Sul e de Santa Catarina. Eles reproduzem conhecimentos e experiências que se configuram num patrimônio desse território por meio da produção agroartesanal. Esta, é continuada, em muitas situações, mesmo diante das forças e do avanço dos agentes no capital no espaço agrário, caracterizando territorialidades sobrepostas e complementares.

Palavras-chave: ritmo; território; desenvolvimento.

\begin{abstract}
In this paper, we reveal some results of our research over the dynamic of territorial units family production that produce food through processing techniques and technologies rudimentary and family work in the municipality of Francisco Beltrão (PR). This production process results from a specific historical and territorial, marked by the colonization held in the Southwestern part of Paraná by German, Pole and Italian descendants from Rio Grande do Sul and Santa Catarina. They reproduce knowledge and experiences that shape a heritage of this territory through the production agroworkmanship. This is continued, in many situations, even in the face of advancing forces and agents of capital in agrarian space, featuring overlapping and complementary territorialities.
\end{abstract}

Keywords: pace; territory; development.

1 Doutorando FCT-UNESP/Presidente Prudente. E-mail: marciofreitaseduardo@yahoo.com.br

2 Colegiado de Geografia - UNIOESTE/Francisco Beltrão. E-mail: saquetmarcos@hotmail.com 


\section{APRESENTAÇÃO}

O tempo lento exprime a lógica das permanências ou das mudanças sem muita intensidade. Qualitativamente, ao que concerne a reprodução do agroartesanato em Francisco Beltrão, este se fundamenta em códigos de territorialidade tradicionais arraigados no patrimônio histórico do modo de produzir (e se auto produzir) familiar. Assim, compreendemos a noção de tempo como um aspecto da (i)materialidade relacional da sociedade na construção de seus territórios e territorialidades.

O tempo lento deriva do patrimônio cultural e é reproduzido por intermédio da razão entre a lógica de sociabilidade dos agentes sintagmáticos no território e a disposição dos elementos técnicos que animam esse mesmo território. Em outros termos a qualidade de permanência do tempo lento não resulta, objetivamente, do tempo mecânico das máquinas e da produção intensiva de mercadorias, mas do tempo de reprodução da vida centrado na lógica de subsistência, sem anular, evidentemente, a produção para o mercado e vice-versa. Trata-se de uma dialética específica de determinadas atividades e territórios.

Em contrapartida, "não há, pois tempos absolutos", como alerta-nos Santos (2002). O que compreendemos pela qualidade de tempo lento só realiza-se em contraposição ao tempo rápido e vice-versa. O território, nessas circunstâncias, afirma-se como um conjunto de temporalidades, uma acumulação desigual de tempos distintos, que se objetiva em ritmos diferentes. A composição dos distintos tempos oriundos em cada arranjo produtivo produz feições territoriais determinadas (circuitos comerciais, agronegócio, produção familiar); feições essas que podem se sobrepor no espaço, conforme as possibilidades de ação em cada sistema territorial.

Desse modo, apresentamos, no artigo, alguns resultados das nossas pesquisas sobre a dinâmica territorial da reprodução do tempo lento da produção agroartesanal e familiar de alimentos, ou simplesmente, do agroartesanato familiar em Francisco Beltrão, Paraná. Estaremos, pois, tratando do território e de expressões de territorialidade da produção familiar, não tipicamente capitalista, em que se concebe a terra e as relações de produção familiares como sustentáculo desse modo de vida. Para efetivação da pesquisa, realizamos levantamentos bibliográficos; coletamos, tabulamos e analisamos os dados secundários que julgamos relevantes e fizemos pesquisa de campo, por meio de entrevistas previamente planejadas com os proprietários das unidades produtivas que estudamos. Procuramos contemplar em nossa pesquisa, a princípio, a totalidade das unidades agroartesanais que eram registradas no Sistema de Inspeção Municipal (SIM). Segundo o relatório da Secretaria Municipal da Agricultura de Francisco Beltrão/PR, existiam, em fevereiro de 2007, trinta e sete agroindústrias artesanais no município em questão. Dessas, realizamos entrevistas com 31 produtores; coletamos dados de 28 unidades (dentre elas de uma agroindústria que não possuía selo de inspeção - família Matiolo) e ainda contemplamos na pesquisa 02 unidades do ramo de pasteurização de leite que tinham encerrado recentemente suas atividades e 01 agroindústria artesanal situada no espaço urbano, conforme consta em Eduardo (2008). As unidades de agroindústrias artesanais estudadas subdividiam-se nos seguintes ramos: a) pasteurização de leite (07 entrevistas); b) produção de queijos (05 entrevistas); c) abatedouro de suínos (05); d) filetagem de pescados (02); e) produção de cachaça (02); f) beneficiamento de mel (02); g) abatedouro de aves (02); h) seleção de ovos (01); i) doces, vinhos e conservas (01); e, j) açúcar mascavo (01).

\section{O PATRIMÔNIO CULTURAL AGROARTESANAL}

O agroartesanato é um patrimônio cultural antigo, tão antigo quanto a história do modo de produzir de seus agentes dinamizadores e é inerente à prática de vida do campesinato. A cultura de produzir, no interior da própria unidade familiar, alimentos como o leite, a canade-açúcar, a carne suína, queijos, embutidos, salames, geléias, frutas diversas, entre outras, transformados ou não, faz parte da lógica da produção familiar. Esta produção agroartesanal como estamos denominando, normalmente, complementa a produção agrícola das unidades produtivas e de vida familiar.

Suas raízes históricas remontam os códigos de territorialidade campesina. Porém, em Francisco Beltrão, município que situa-se no Sudoeste paranaense, constatamos um "recente" e notável dinamismo desse tipo tradicional de produção de alimentos. E trataremos de ponderar seus elementos basais.

O agroartesanato, sob nossa ótica de análise, trata-se de uma atividade de produção e transformação de alimentos que se efetiva no interior da própria unidade familiar de produção, atividade que mobiliza força de trabalho familiar e instrumentos artesanais de produção para sua realização.

Nas literaturas clássicas sobre a questão agrária, entre elas a de K. Kautsky, encontramos referências ao modo de produzir agroartesanal. Kautsky (1986) analisa o agroartesanato a partir de um contexto mais amplo do que nos propomos aqui, englobando a atividade no que ele designa por "indústria caseira" (incluindo o ar- 
tesanato em madeira, mármore, tabaco, lã, ferramentas etc.). Kautsky (1986) destaca que o camponês recorre ao sistema produtivo de "industrialização caseira sempre que a atividade agrícola falhar como fonte exclusiva de sustento de sua família". A atividade é analisada por Kautsky enquanto resquício feudal camponês, cujas possibilidades de realização são possíveis apenas em condições extremamente desfavoráveis ao desenvolvimento da grande exploração capitalista.

Em Francisco Beltrão a expansão recente da atividade denota, contraditoriamente, um fluxo no refluxo da agricultura familiar, ou seja, a cristalização do agroartesanato sinaliza uma forma de resistência do agricultor ao modelo do agronegócio efetivado pelo sistema convencional de integração contratual.

A atividade agroartesanal difundida localmente - e também no Sudoeste paranaense - é praticada, sobretudo, por descendentes de italianos, alemães e poloneses; consolida-se, na atualidade, como trunfo do território da produção familiar, como elemento de resistência frente às estreitezas engendradas regionalmente pela expansão crescente do paradigma de produção do agronegócio, como constatamos em Eduardo (2008).

Para entendermos os elementos constituintes da dinâmica territorial do agroartesanato beltronense é imprescindível que façamos um breve resgate histórico das particularidades intrínsecas ao processo de colonização do Sudoeste paranaense, pois, os aspectos materiais e imateriais do movimento de colonização estão na base da gênese do agroartesanato regional.

Posteriormente, embasados em dados da EMATER, IPARDES, IBGE, Prefeitura Municipal de Francisco Beltrão/PR e de trabalhos de campo constantes em Eduardo (2008), trataremos de explicitar aspectos da territorialização do agroartesanato frente à expansão do capitalismo agrário regional; para tanto, selecionamos três famílias para evidenciarmos algumas características de suas organizações territoriais.

\section{A GÊNESE DO AGROARTESANATO NO SUDOESTE DO PARANÁ}

A mesorregião em que está circunscrito o nosso objeto de estudo tem a especificidade imanente de ser a última área de expansão da fronteira agrícola do estado do Paraná. Uma região praticamente inóspita antes de 1940 ou, no dizer de Wachowicz (1985), um "vazio demográfico". No início do século XX viviam, no Sudoeste paranaense, desde Mariópolis até a fronteira com a República da Argentina, cerca de 3.000 habitantes. Mesorregião habitada hoje por mais de meio milhão de habitantes e composta por 37 municípios (IBGE, 2000).

Na primeira fase de ocupação (até 1940), além das práticas agrícolas primitivas territorializadas pelos caboclos, mescladas com atividades também primitivas de caça, pesca e coleta, ainda se desenvolveram outras atividades produtivas como coleta de erva-mate, extração de madeira - destacando-se, em ambas as atividades, o contrabando por parte de argentinos e paraguaios - e a criação de suínos soltos. Esses diferentes conjuntos de relações expressavam as principais atividades produtivas territorializadas no Sudoeste, nos primórdios de sua ocupação. Esse panorama pouco se alterou até os anos de 1940.

Uma multiplicidade de elementos influenciou na colonização efetiva do Sudoeste do Paraná, conforme demonstram autores como Feres (s/d), Wachowicz (1985), Saquet (2005) e Lazier (1997). Como indica Feres (s/d), Getúlio Vargas tinha muitos motivos para estimular o processo de abertura da fronteira sudoestina, tendo em vista

[...] a necessidade de resolver o problema de escassez de terras e de emprego rural em seu próprio estado de origem, o Rio Grande do Sul; a necessidade de dar forma à ideologia propagada pelo Estado Novo, através do programa Marcha para o Oeste, centrado na necessidade de fixação do homem à terra, pela criação de novas oportunidades de emprego rural nas áreas despovoadas do país; e a necessidade de cumprir o objetivo geopolítico, inspirado na Lei de Segurança Nacional, de ocupação da faixa de fronteira por um campesinato próspero, socialmente calmo e politicamente conservador, como tampão às infiltrações de contrabandistas argentinos e paraguaios na área (FERES, p. 498 - grifo nosso).

Em 1943, para atender a eminente demanda social oriunda das contradições acirradas no Rio Grande do Sul (desemprego rural, fracionamento da propriedade fundiária, rendas decrescentes originadas pela queda da fertilidade natural do solo, entre outros elementos) Getúlio Vargas cria a Colônia Agrícola Nacional General Osório (CANGO). Nessa década, estabeleceu-se, no Sudoeste do Paraná, como aponta Feres (s/d), práticas migratórias de ocupação efetiva da fronteira e de facilitação de investimentos privados sob a forma de doações de terras desocupadas, mediante vendas simbólicas. No plano de ação da CANGO constava, doravante, a implementação de infraestrutura como estradas, escolas, hospitais etc., fazendo com que se intensificasse a circulação de mercadorias na região.

No intuito de demonstrarmos tal fenômeno, valemo-nos de Wachowicz (1985), que revela indícios 
da intensidade com que foi ocupado o Sudoeste paranaense através da intervenção estatal. Segundo o autor, o número de famílias cadastradas pela CANGO, em apenas uma década - entre 1947 e 1956 - aumentou mais de cinco vezes, ou seja, de 467 famílias cadastradas em 1946, passam para 2.725 em 1956.

Os migrantes, preponderantemente gaúchos e catarinenses reterritorializaram-se regionalmente, produzindo territórios e imprimindo-lhes características e temporalidades específicas suplantando os códigos culturais de expressão cabocla. A propriedade privada, instituída no Sudoeste paranaense a partir da conhecida "Revolta dos Colonos de 1957" e da atuação do GETSOP (Grupo Executivo para as Terras do Sudoeste do Paraná) fez com que a terra permutasse do valor de uso para valor de troca - fundamento para a formação do mercado interno regional, estímulo ao surgimento de pequenas cidades, comércios, pavimentações, sistema de créditos etc.

Em 1950, como aponta Alves et al. (2004):

a maior parte do Sudoeste paranaense estava ocupada (pela frente colonial) e havia uma rede viária estabelecida integrando-o internamente e permitindo que novos capitais passassem a migrar entre os diferentes territórios [...] (ALVES et al., 2004, p. 151).

No Sudoeste do Paraná, a pequena propriedade esteve na base da estrutura fundiária adotada através da CANGO, reproduzindo as mesmas bases territoriais estabelecidas no Rio Grande do Sul e em Santa Catarina. Mesmo com o passar das décadas, essa forma específica de organização da estrutura fundiária predomina. Aproximadamente $95 \%$ das propriedades rurais existentes no Sudoeste paranaense estão situadas em estratos de área que não excedem 50 hectares (IBGE, 1995/96).

Ainda assim, a economia do Sudoeste paranaense, até 1960, praticamente, dependia da policultura de subsistência e, de maneira menos intensa, da extração de madeira, da erva-mate e da criação de animais (galinhas, porcos, bovinos etc.), efetuada, em geral, em pequenas propriedades rurais e com base no trabalho familiar.

\section{A RETERRITORIALIZAÇÃO DOS MIGRANTES NO SUDOESTE PARANAENSE}

No processo de colonização do Sudoeste do Paraná, há um aspecto que se destaca: a composição étnico-cultural da população reterritorializada. $\mathrm{Na}$ formação histórica da mesorregião, a cultura exerceu centralidade importante, notoriamente ao que tange à reprodução e difusão de um conhecimento agroartesanal - um saber fazer produtivo transmitido ao longo de gerações e que tem seu epicentro histórico nos códigos culturais do campesinato italiano, polonês e alemão, sobretudo.

Os migrantes gaúchos e catarinenses constituíam-se majoritariamente como descendentes de pais e avós, sobretudo camponeses, que já haviam, no século XIX, sofrido processos de desterritorialização em alguns países da Europa, principalmente na Itália, Alemanha e Polônia, e que, em momento posterior, por força das determinações sociais, implícitas na reprodução ampliada do capital, reterritorializaram-se no Centro-Sul do Brasil, principalmente nos estados do Rio Grande do Sul, Santa Catarina e São Paulo.

A desterritorialização italiana para o Brasil, por exemplo, foi um processo resultante, segundo Saquet (2003), do movimento de expansão do capitalismo que:

[...] expropriou para apropriar no Brasil e em outros lugares; expropriou para ter força de trabalho à disposição dos industriais emergentes e dos latifundiários. A mudança de uma formação socioeconômica feudal para o modo de produção predominantemente capitalista produziu novas formas de propriedade, de apropriação e de produção do espaço e do território na Itália [...]. Deste modo, o capital expande seus tentáculos lentamente no espaço agrário italiano, envolvendo milhares de longínquos produtores agrícolas e artesanais (SAQUET, 2003, p.57-58).

Como enfatiza o mesmo autor, a colonização italiana no extremo Sul do Brasil foi promovida com um conteúdo complementar, porque era necessário satisfazer as cobranças externas sobre a situação dos imigrantes no Brasil e produzir alimentos para o mercado interno. O capital, em sua natureza, apropria para explorar, promovendo um movimento constante erigido com base na des-re-territorialização da força de trabalho.

Para Saquet (2003), o movimento de formação de uma economia de mercado, na Itália, levou à mobilidade territorial da força de trabalho no final do século XIX, emigrando "camponeses pobres, sem capital familiar para melhorar a produção e camponeses expropriados [...]" ( SAQUET, 2003, p. 62).

Porém, se, por um lado, a permanência da produção familiar com técnicas rudimentares agravou a situação de vida dos camponeses, por outro, a lenta introdução de algumas técnicas em algumas unidades produtivas liberou força de trabalho. Emigraram porque eram pobres, com uma economia familiar estacionária e 
porque houve a introdução de novas técnicas e tecnologias em produções que absorviam, até então, parte do excedente de força de trabalho da família agricultora (SAQUET, 2003, p. 70).

O autor argumenta que, em suas territorialidades cotidianas, os italianos eram apegados a valores ligados à permanência, à estabilidade, aos costumes, à obediência. Toda essa estrutura era alicerçada numa base fundamentalmente patriarcal, culturalmente envolvida num tradicionalismo conservador, que se materializa em seus bens culturais, como no caso da produção agroartesanal de salames, copas e vinhos.

Os italianos almejavam tornarem-se proprietários de seus próprios meios de produção (terras, comércios e manufaturas - moinhos, alfaiataria etc.); contribuíram efetivamente para a formação do mercado interno nos estados de Rio Grande do Sul e Santa Catarina. Como menciona Franco Cenni:

O sonho de todo modesto agricultor italiano que, atravessando o oceano, enfrentava o desconhecido, depois de ter visto pais e avós trabalhando durante toda a vida terras de outrem, era certamente o de possuir seu campo, sua casa, de poder fazer sua colheita e poupar o fruto de seu trabalho, garantindo um futuro melhor para seus descendentes. Era o que eles iriam encontrar na então província do Rio Grande do Sul numa forma de colonização verdadeiramente ideal não apenas para os agricultores mas para o próprio rápido desenvolvimento das culturas, pois não haveria colonos assalariados, mas inúmeros pequenos proprietários, homens humildes e trabalhadores, em condições de realizar da melhor forma seu sonho de abastança, que para muitos se transformaria em riqueza (CENNI, 2003, p.155).

As atividades artesanais (agrícolas e urbanas) eram comuns entre os italianos, alemães e poloneses. Com técnicas artesanais, essas atividades cumpriam (e ainda cumprem) o papel de subsistência sob a lógica da policultura familiar. A adaptação necessária as condições adversas de vida entremeio ao "sertão" a ser desbravado fez florescer no Rio Grande do Sul uma economia familiar densa, coesa, apoiada na auto-suficiência produtiva das famílias recém territorializadas.

Traço característico do agricultor italiano, recebido de seus ascendentes e transmitido aos filhos, é a preocupação de plantar e colher em suas próprias terras o necessário para o sustento de sua família. Sóbrio e parcimonioso, vive ele de maneira quase sempre modesta, mas a mesa é farta. E para isso se dedica, quando encontra condições favoráveis de clima, àquela policultura que tem sempre, de início, o objetivo de suprir ao consumo familiar (CENNI, 2003, p.167-168).
As atividades artesanais urbanas também denotavam características culturais dos imigrantes mencionados, profissões como de ferreiro, oleiro, carpinteiro, alfaiate etc. eram comuns e foram efetivadas nas áreas de colonização eurobrasileiras juntamente com práticas culturais, como demonstra Saquet (2003):

Apesar da forma de apropriação dos lotes rurais, conseguiram reproduzir na colônia [Silveira Martins/ RS], além de características de suas produções agrícolas e artesanal, elementos de seu modo de vida cultural, através da alimentação (polenta, massas, vinho, salame, fortaglia, queijos...), das roupas, da religião (igrejas, santos, capitéis, cantos, festas etc.) e dos próprios dialetos, constituindo no território local, territórios [...] (p. 105)

\section{E acrescenta que,}

As atividades artesanais alimentícias e de vestuário, intimamente ligadas à economia e à unidade produtiva familiar também se mantiveram. A diversidade das produções artesanais continua sendo fruto das necessidades impostas pelas atividades cotidianas e da falta e precariedade das vias e meios de circulação e comunicação (SAQUET, 2003, p. 130).

Imigrantes, agora feitos gaúchos e catarinenses, suas gerações perpetuadas constituem-se em personificação e representação de seus próprios trunfos culturais. Porém, a lógica do capital também se desenvolve instaurando suas contradições. $O$ desgaste do solo por técnicas agropecuárias rudimentares, aliado à contínua vinda de imigrantes ao Rio Grande do Sul e Santa Catarina e o crescimento natural da população, fizeram com que o fracionamento excessivo da propriedade agrícola tornasse insustentável o modelo exploratório implantado baseado naqueles parâmetros. Analisando as colônias alemãs no Rio Grande do Sul, Roche (1969) pondera-nos que:

Se o esgotamento do solo é o pesadelo de tôdas as colônias, foi a conservação da técnica da queimada que empobreceu, de um lado, a coletividade, calcinando as terras, e, de outro, o próprio colono, reduzindo o rendimento progressivamente [...] a agricultura dos colonos, condenada a procurar sempre outras terras virgens deslocou-se, cada vez mais depressa, através do espaço rio-grandense, cujos limites agora atinge (ROCHE, 1969, p. 295).

No primeiro triênio do século $X X$, o processo de migração - ao longo do interior do Brasil, onde existiam vastas áreas propícias ao avanço da fronteira agrícola - foi uma forma intensamente praticada por gaúchos e catarinenses condicionados a migrar. 
EDUARDO, M. F.; SAQUET, M. A. Elementos do ritmo lento da territorialização do...

O Sudoeste e o Oeste paranaenses, grande parte do Mato Grosso do Sul, Mato Grosso e Rondônia (Oeste brasileiro) foram destinos pretendidos pelos fluxos migratórios que ganhavam corpo. Em áreas de colonização, estão ali afloradas as possibilidades do desenvolvimento do tempo lento mescladas às formas embrionárias de desenvolvimento capitalista - através da policultura de subsistência, do agroartesanato e de outras relações não tipicamente capitalistas de produção.

O agroartesanato é uma dessas permanências do tempo lento, reproduzido pelos eurobrasileiros em seu processo de dispersão territorial pelo Brasil, afirmando-se como atividade produtiva tradicional, de subsistência e/ou mercantil: uma rugosidade, reflexo de um patrimônio cultural herdado.

As informações constantes no Quadro 1 acerca da etnia e origem das famílias que pesquisamos
(EDUARDO, 2008) ratificam a supremacia de gaúchos e catarinenses no tocante as iniciativas em torno da atividade agroartesanal. Cabe destacar que muitas famílias pesquisadas foram pioneiras no processo de colonização da mesorregião e, através das entrevistas e dos levantamentos de dados, pudemos constatar as diversas determinações que motivaram o desenvolvimento recente do agroartesanato em cada unidade de produção familiar.

No Sudoeste do Paraná, os descendentes de alemães, poloneses e italianos reproduzem determinadas práticas econômicas como cultivo dos parreirais, da cevada e da instalação de moinhos, serrarias e sapatarias; a transformação da carne suína em salames e outros derivados; atividades culturais, através de festas, danças e canções; a religiosidade e, ainda, aspectos de sua organização política, especialmente práticas de ajuda mútua e associações que ainda permanecem.

\begin{tabular}{|c|c|c|c|}
\hline $\begin{array}{l}\text { Produtores } \\
\text { entrevistados }\end{array}$ & Etnia & Local de origem da família & $\begin{array}{c}\text { Ano em que a família se estabeleceu } \\
\text { em Francisco Beltrão }\end{array}$ \\
\hline 1 & Italiana & Araquiba/RS & 1988 \\
\hline 2 & Italiana & Passo Fundo/RS & 1958 (2003 - propriedade) \\
\hline 3 & Italiana & Veranópolis/RS & 1955 \\
\hline 4 & Italiana & Erechim/RS & 1957 \\
\hline 5 & Italiana & Nova Prata/RS & 1949 (1987 - propriedade) \\
\hline 6 & Alemã & São Maurício/SC & 1994 \\
\hline 7 & Italiana & Bento Gonçalves/RS & 1964 \\
\hline 8 & Polonesa & Gaurama/RS & 1954 \\
\hline 9 & Alemã & Itapiranga/SC & 1988 \\
\hline 10 & Alemã & Rio dos Ovos/SC & 1952 \\
\hline 11 & Italiana & Joaçaba/SC & 1956 \\
\hline 12 & Italiana & Guaporé/RS & 1968 \\
\hline 13 & Italiana & Passo Fundo/RS & 1956 \\
\hline 14 & Alemã & Ituporanga/SC & 1947 \\
\hline 15 & Italiana & Rio do Sul/SC & 1956 (2004 - propriedade) \\
\hline 16 & Italiana & Urussanga/SC & 1953 \\
\hline 17 & Italiana & Passo Fundo/RS & 1952 \\
\hline 18 & Italiana & Nova Prata/RS & 1954 \\
\hline 19 & Polonesa & São Mateus do Sul/PR & 1952 \\
\hline 20 & Italiana & Erechim/RS & 1958 \\
\hline 21 & Polonesa & Erechim/RS & 2001 \\
\hline 22 & Polonesa & São Mateus do Sul/PR & 1952 \\
\hline 23 & Italiana & Santa Rosa/RS & 1980 \\
\hline 24 & Alemã & Orleans/SC & 1950 (1985 - propriedade) \\
\hline 25 & Italiana & Machadinho/RS & 1964 (2003 - propriedade) \\
\hline 26 & Alemã & Orleans/SC & 1950 (1985 - propriedade) \\
\hline 27 & Italiana & Capanema/PR & 1994 \\
\hline 28 & Italiana & Passo Fundo/RS & 1958 \\
\hline
\end{tabular}

QUADRO 1 - ETNIA E LOCAL DE ORIGEM DOS PROPRIETÁRIOS DAS UNIDADES PRODUTIVAS ESTUDADAS (FRANCISCO BELTRÃO)

FONTE: Eduardo (2008). 
As unidades produtoras de alimentos que analisamos têm como característica um ritmo de produção lento, artesanal, com centralidade no trabalho familiar e com uma abrangência de mercado eminentemente local (EDUARDO, 2008).

A produção artesanal e familiar efetiva-se como uma atividade não especificamente capitalista. Nessa lógica, as relações de trabalho familiares, a propriedade da terra e dos instrumentos de trabalho otimizam o ciclo da reprodução familiar. Sob a ótica mercantil do modo capitalista de produção, ingressam no mercado, perifericamente sob o que Marx (2002) designou de "circulação simples de mercadoria".

Com a prática do agroartesanato, busca-se, fundamentalmente, agregar mais valor ao trabalho familiar, por intermédio da produção e transformação intraunidade (in loco) de alimentos e a venda direta ao consumidor. Sob esses parâmetros constata-se maior autonomia na organização desse território, tendo em vista a baixa participação do capital comercial, industrial e financeiro nos parâmetros de produção e circulação das mercadorias das unidades agroartesanais familiares.

Como permanência histórica de uma forma antiga de transformar alimentos, as técnicas e os instrumentos de trabalho artesanais de produção representam a reprodução local de um conhecimento tradicional herdado no contexto da reterritorialização italiana e alemã no Sul do Brasil, conforme mencionamos anteriormente.

Celso Polla, produtor de mel, informando-nos sobre o início da atividade menciona que:

Isso não é por acaso, né, já vem de herança. Já faz trinta anos que lido com abelha. Meu nono lidava com abelha, né, meu pai lidava com abelha e eu continuo com abelha. Eu, no começo, foi por gosta mesmo; trabalhava, era empregado, no banco do Estado do Rio Grande e, nas horas vagas, comecei com abelha, né. Mas antes disso, com o pai eu já trabalhava com abelha lá no Rio Grande. Daí, como abriu esse caminho para a agroindústria, cresceu a fiscalização prá poder vender o mel mais fácil, né. Se não fosse isso não adiantava colher, vender pra intermediário ganhar um precinho.

Este depoimento demonstra o que chamamos de saber fazer produtivo agroartesanal. Trata-se de um conhecimento produtivo acumulado através das gerações, portanto, assimilado nas territorialidades familiares. Pode-se constatar esse mesmo patrimônio cultural do agroartesanato, por exemplo, nas porções ocidentais do Rio Grande do Sul e de Santa Catarina, principais locais de origem dos migrantes que se deslocaram para o Sudoeste e o Oeste do Paraná.
É importante esclarecer a particularidade cultural do saber fazer produtivo dos colonos eurobrasileiros, difundido localmente na formação territorial do Sudoeste do Paraná e diferenciar a atividade agroindustrial artesanal das grandes unidades agroindustriais tipicamente capitalistas, integradoras, nós constitutivos das redes sustentadas pelos preceitos organizacionais dos complexos agroindustriais (CAls).

Doravante, caminhando no terreno da explicação, alguns pontos em comum identificam as unidades agroartesanais: a) são pequenas unidades de produção de alimentos (em espaço físico e produção); b) produzem no intuito de atender nichos de mercado locais ou, em raras situações, regionais; c) a mão-de-obra dos membros da família basta, na maioria das vezes, para atender a demanda do processo produtivo; d) têm sua dinâmica vinculada à economia agropecuária intraunidade; e) sustentam-se em práticas, conhecimentos e experiências herdadas de geração em geração.

$\mathrm{Na}$ atividade agroartesanal sudoestina, particularidades como a do elemento cultural espelhado na territorialização do saber fazer produtivo, das relações familiares, da policultura de subsistência, do ritmo artesanal produtivo e da territorialidade de mercado são trunfos do território e precisam ser levadas em consideração no conjunto das expressões territoriais.

\section{MODERNIZAÇÃO AGRÍCOLA NO SUDOESTE (PR): DESENVOLVIMENTO E CONFLITUALIDADES}

Em consonância com os fundamentos de sua reprodução ampliada, o capital apropria para explorar. Essa apropriação traz à tona o desenrolar das conflitualidades cotidianas entre as distintas classes sociais em defesa de seus territórios: assim processa-se a questão agrária sob a luz do conflito entre o agronegócio e o território da agricultura familiar.

O capital, para se apropriar da capacidade de produção de riqueza do território da agricultura familiar, age sob duas facetas: 1) através da desterritorialização ou 2) por intermédio da "monopolização do território pelo capital” (OLIVEIRA, 2001). Dessas facetas de ação do capital originam-se as conflitualidades, envolto ao que Fernandes (2008, p. 208) caracteriza por "disputas territoriais": "Territórios capitalistas e não capitalistas produzem permanente conflitualidades pela disputa territorial".

Para nós, o agroartesanato é uma atividade que representa uma estratégia de luta do produtor familiar pelo exercício de hegemonia de seu próprio território. A revitalização dessa atividade, no Sudoeste paranaense, 
EDUARDO, M. F.; SAQUET, M. A. Elementos do ritmo lento da territorialização do...

num momento de expansão das atividades capitalistas, remete-nos a pensar sobre a importância do uso do território para o equilíbrio do status quo das centralidades não capitalistas de produção na agricultura. Na disputa territorial, essa revitalização da atividade agroartesanal familiar expressa o sentido de trunfo territorial face as conflitualidades avolumadas com a expansão do capital.

No Sudoeste paranaense, a partir da década de 1970, constata-se um processo de modernização agropecuária: incremento da base técnica da produção, especialização produtiva e aumento de produtividade de algumas culturas como a soja, o fumo e o milho, em detrimento de culturas tradicionais como o arroz e o feijão. Ocorre também, no decorrer da década de 1980, a introdução de grandes complexos agroindustriais nas áreas de tabaco, frangos, suínos e leite. Tudo isso se desenrola em consonância com essa estrutura territorial específica de que tratamos anteriormente. Recorramos à análise de alguns dados a título de exemplificação:

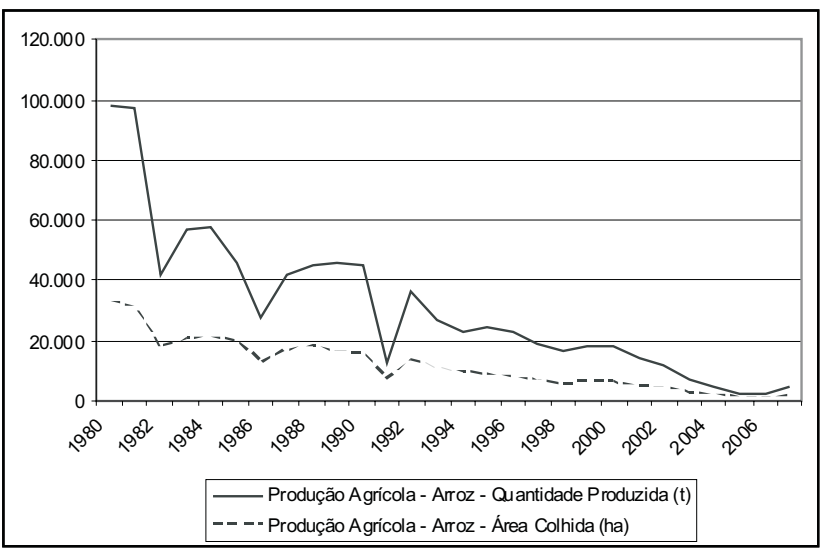

GRÁFICO 1 - SUDOESTE PARANAENSE - PRODUÇÃO AGRÍCOLA: ARROZ - QUANTIDADE PRODUZIDA E ÁREA COLHIDA ENTRE 1980 E 2007.

FONTE: IBGE; Org. dos dados: IPARDES.

A análise dos Gráficos 1 e 2 nos concede a dimensão da disparidade existente entre a evolução das produções agrícolas de arroz e soja. Na mesorregião Sudoeste do Paraná, a produção de soja (área colhida e quantidade produzida) aumenta consideravelmente entre 1980 e 2007 em detrimento da produção de arroz. Entre o mesmo recorte temporal, no município de Francisco Beltrão, a área colhida de arroz diminuiu 11 vezes (de 990 ha para 90 ha) e a quantidade produzida diminuiu 10 vezes - das 1.782 toneladas produzidas em 1980, passa-se para 180 toneladas em 2007, conforme dados do IBGE - retrato da expansão capitalista na agricultura, cuja sistemática de mercado impulsiona a produção de culturas "mais rentáveis", como as de commodities.

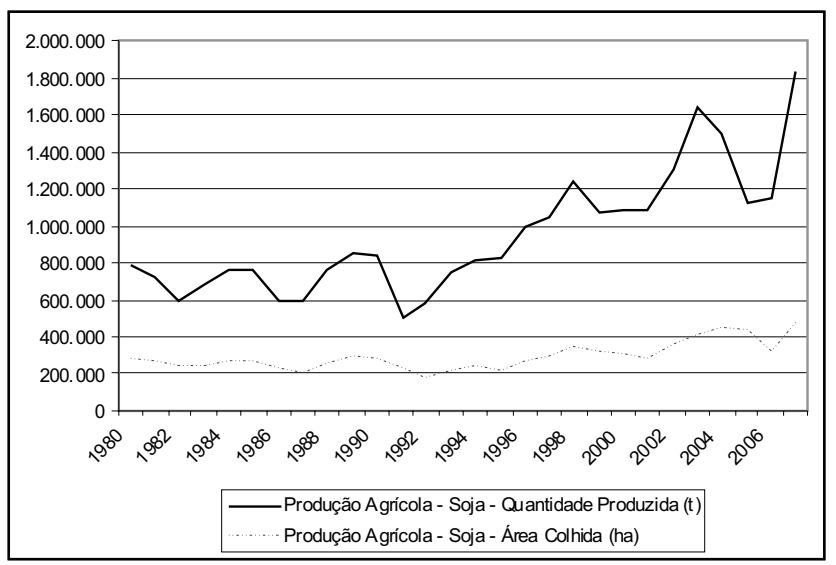

GRÁFICO 2 - SUDOESTE PARANAENSE - PRODUÇÃO AGRÍCOLA: SOJA - QUANTIDADE PRODUZIDA E ÁREA COLHIDA ENTRE 1980 E 2007

FONTE: IBGE; Org. dos dados: IPARDES.

O final da década de 1980 e, sobretudo, a década de 1990, é marcada ainda pela territorialização de grandes agroindústrias integradoras no Sudoeste paranaense, como a Souza Cruz, a Sadia, a Perdigão e a Parmalat. Os dados sistematizados nos Gráficos 3 e 4 dão-nos nota da intensidade em que se territorializou o agronegócio do fumo e do leite regionalmente. Veementemente expandiram-se as cadeias produtivas referidas.

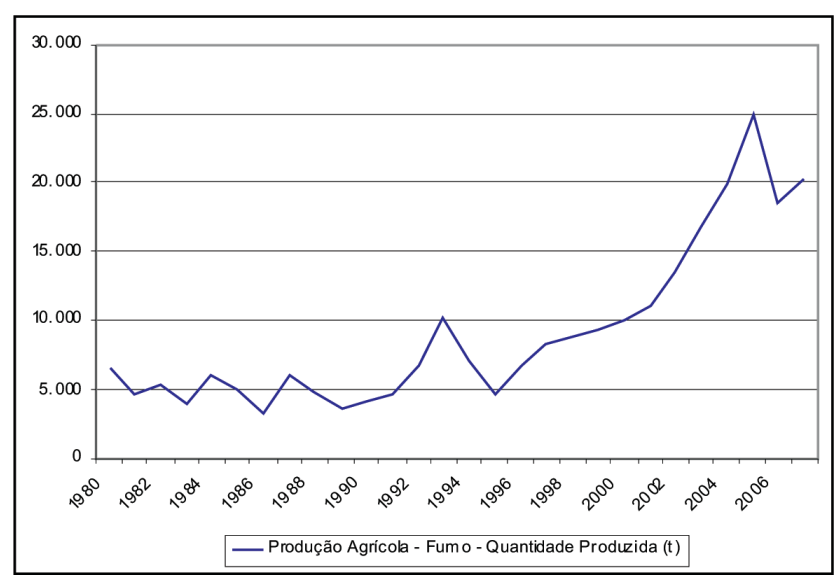

GRÁFICO 3 - SUDOESTE PARANAENSE - PRODUÇÃO AGRÍCOLA: FUMO - QUANTIDADE PRODUZIDA ENTRE 1980 E 2007

FONTE: IBGE; Org. dos dados: IPARDES.

Ancorado na sistemática produtivista dos CAls, elevou-se, em consequência, a composição orgânica do capital e, consigo, o processo de subordinação da agricultura familiar nos lugares onde territorializaram essas atividades. 
EDUARDO, M. F.; SAQUET, M. A. Elementos do ritmo lento da territorialização do...

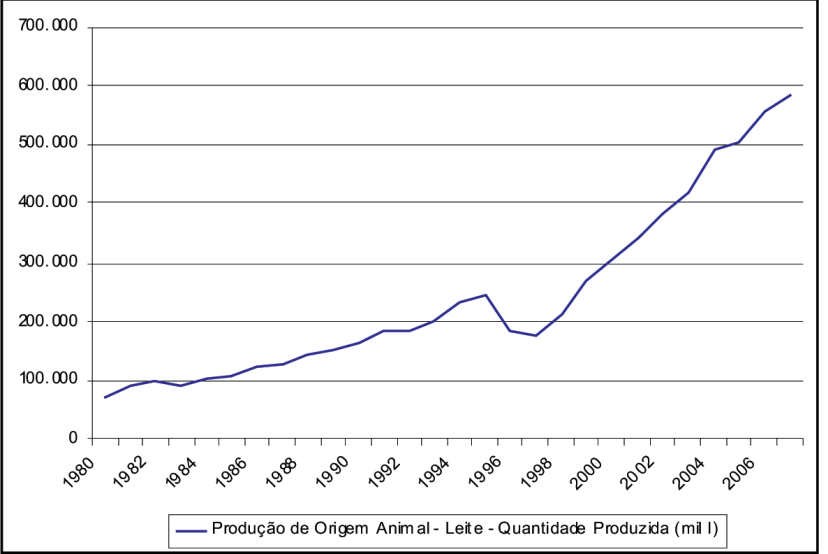

GRÁFICO 4 - SUDOESTE PARANAENSE - PRODUÇÃO DE ORIGEM ANIMAL: LEITE - QUANTIDADE PRODUZIDA ENTRE 1980 E 2007

FONTE: IBGE; Org. dos dados: IPARDES.

A partir da década de 1980 , a produção de galináceos ganha estímulo com a territorialização de agroindústrias integradoras como a Sadia, a Perdigão, a Diplomata e a Anhambi. O efetivo de galináceos no Sudoeste paranaense, que somava 5.286 .832 unidades em 1980, é ampliado para 44.212.465 em 2007: uma elevação que corresponde a $780 \%$. Com a reestruturação produtiva dos complexos agroindustriais, aguçada na década de 1980, o capital, como aponta Oliveira
(2002) uniu o que no início separou: a indústria e a agricultura.

Karl Marx já observava no século XIX os efeitos de subordinação que o capital industrial promove ao estender sua influência territorial ao espaço rural. $\mathrm{O}$ autor sustenta que

a produção capitalista, portanto, só desenvolve a técnica e a combinação do processo social de produção, exaurindo as fontes originais de toda a riqueza: a terra e o trabalhador (MARX, 2002, p. 571).

Outra consequência do movimento de modernização da agricultura associa-se a questão da mão-de-obra ocupada, com efeito, a população rural tem diminuído desde a década de 1970, ao passo que, somente em dez anos, entre 1996 e 2006, segundo censos agropecuários do IBGE, diminuiu em $20 \%$ o número de pessoal ocupado em estabelecimentos agropecuários no Sudoeste paranaense. Em 1996 o total de pessoal ocupado correspondia a 159.560 pessoas. Já em 2006, a força de trabalho restringe-se a 127.450. Contudo, uma considerável parte da população sudoestina ainda exerce suas atividades no setor primário: somam-se $41,4 \%$ da população ocupada de 10 anos de idade ou mais, segundo IBGE (2000), ou seja, aproximadamente 92 mil pessoas, consoante podemos observar na Tabela 1, a seguir:

TABELA 1 - NÚMERO E PERCENTUAL DE PESSOAS DE 10 OU MAIS ANOS DE IDADE OCUPADAS POR SETORES DA ECONOMIA NO SUDOESTE DO PARANÁ (1970-2000)

\begin{tabular}{|c|c|c|c|c|c|c|c|}
\hline \multirow{3}{*}{ Ano } & \multicolumn{6}{|c|}{ Setores da economia } & \multirow{3}{*}{$\begin{array}{c}\text { Total de } \\
\text { pessoas } \\
\text { ocupadas }\end{array}$} \\
\hline & \multicolumn{2}{|c|}{ Primário } & \multicolumn{2}{|c|}{ Secundário } & \multicolumn{2}{|c|}{ Terciário } & \\
\hline & $\mathrm{n}$. & $\%$ & $\mathrm{n}$. & $\%$ & $\mathrm{n}$. & $\%$ & \\
\hline 1970 & 127.470 & 82,73 & 8.186 & 5,31 & 18.423 & 11,96 & 154.079 \\
\hline 1980 & 128.254 & 64,77 & 21.939 & 11,08 & 47.809 & 24,15 & 198.002 \\
\hline 1991 & 119.192 & 55,43 & 26.623 & 12,38 & 69.203 & 32,19 & 215.018 \\
\hline 2000 & 92.193 & 41,41 & 43.162 & 19,39 & 87.280 & 39,20 & 222.635 \\
\hline
\end{tabular}

FONTE: IBGE/Censos demográficos (1970, 1980, 1991 e 2000).

Mesmo havendo aumento no total absoluto de pessoas ocupadas na soma dos três setores da economia no Sudoeste paranaense, podemos perceber nitidamente a ocorrência de uma redução significativa de pessoas ocupadas no setor primário, com variação negativa de mais de $40 \%$ entre as décadas de 1970 e 2000. Esse índice alastra-se ainda mais se considerarmos os resultados preliminares do censo agropecuário do IBGE de 2006 ao qual fizemos referência anteriormente. Paralelamente, o número de pessoas ocupadas no setor secundário aumentou de 5,31\% em 1970, para $19,39 \%$ em 2000 . O mesmo acréscimo nota-se na dinâmica do setor terciário. Em 1970, o setor terciário envolvia $11,6 \%$ do pessoal ocupado enquanto o percentual aumentou para $39,2 \%$ em 2000 , revelando mudanças significativas na economia regional através da industrialização e da maior complexidade das atividades de serviços em cidades como Francisco Beltrão, Pato Branco e Dois Vizinhos. 
Em decorrência da modernização da agricultura processa-se a substituição da mão-de-obra ocupada em lavouras de commodities, que, por sua vez, incitam a uma maior complexidade da base técnica das explorações agropecuárias e a uma maior especialização do trabalho. Além disso, no Sudoeste do Paraná, a partir dos anos de 1980, ocorre uma diversificação do incremento da produção industrial, juntamente com o crescimento de cidades como as mencionadas anteriormente.

Complementando a análise, percebemos que a redução das ocupações no setor agropecuário do Sudoeste paranaense também se justifica pelo fato do aumento de outras despesas no setor (base técnica); por exemplo, houve o aumento das despesas com adubos, corretivos, defensivos agrícolas e com rações em detrimento dos gastos com serviços típicos de empreitada e de gastos com salários: uma evidência das transformações regionais instauradas com a modernização da agricultura.

É importante destacar que essas transformações vêm cristalizando-se no espaço agrário do Sudoeste paranaense onde a difusão recente do agroartesanato vincula-se a esse movimento mais geral do capital: como resposta e resistência às transformações e conflitualidades que se apresentam no âmago do paradigma do agronegócio.

Ao longo das gerações, a reprodução cultural de conhecimentos e experiências produtivas acumuladas (transmissão de receitas, produção dos cultivares, transformação de matérias-prima etc.) constitui elementos significativos para pensarmos a territorialidade regional do saber fazer produtivo artesanal e familiar - de descendência italiana, alemã e polonesa. De fato, para os sujeitos sociais envolvidos, a importância que a produção agroartesanal assume, no momento atual, para muitas famílias, é algo surpreendente, como ocorre em Francisco Beltrão (PR): para $86 \%$ das famílias que estudamos a produção agroartesanal de alimentos constitui a principal fonte de renda da família.

\section{DETALHANDO A PRODUÇÃO AGROARTESANAL EM FRANCISCO BELTRÃO/PR}

É difícil precisar a quantidade de agroindústrias artesanais existentes no Sudoeste paranaense, devido justamente ao seu caráter artesanal, doméstico. Constatamos uma disseminação da atividade agroartesanal nas condições mais variáveis que possamos imaginar. Conforme levantamentos da EMATER (2003), no Estado do Paraná, existem, aproximadamente, 1.272 agroindústrias do tipo artesanal, que processam diversos produtos nos diferentes ramos produtivos, dentre eles destacam-se como principais os de derivados de leite, de carne suína, de pescados, de cana-de-açúcar, de vegetais e de panificação.

Com relação ao número de agroindústrias artesanais existentes no Sudoeste do Paraná, a única fonte de dados existente a que podemos recorrer é a do "Plano de desenvolvimento sustentável do Sudoeste do Paraná", elaborado pela EMATER em 1999. Nesse relatório, consta um total de 305 unidades no Sudoeste paranaense (42 municípios). Dessas agroindústrias, 46,6\% (127 unidades) possuíam registro de inspeção (86 unidades pelo Selo de Inspeção Municipal, 26 pelo Selo de Inspeção Paranaense, 06 pelo Selo de Inspeção Federal e 09 estabelecimentos com outros tipos de registros). Ou seja, mais da metade das agroindústrias de que se tinha conhecimento no período $(53,4 \%$ ou 178 unidades) operavam clandestinamente.

A modernização da agricultura acarretou na expansão do agronegócio regional. A agroindústria artesanal, nesse contexto, atua no sentido de propiciar a geração de renda às famílias envolvidas (em dinheiro - semanal ou mensal), fazendo da cooperação familiar elemento essencial da territorialidade produtiva e da resistência. Inclusive as crianças auxiliam no trabalho agroartesanal num processo contínuo do que concebemos por educação para o trabalho.

Lá é assim, leite tudo junto, queijo tudo junto, vai lá vende, deu tanto, reparte e deu tanto. Daí tem que comprar medicamento, comprar ração, ferramenta, alguma coisa daí compra as ferramentas, deu tanto daí reparte e os aviários também é assim. Pra colocar uma agroindústria sozinho é meio difícil. Aqui envolve as três famílias daí tu consegue tocar, né. Nós somos num total de treze. A piazada ajuda, sete, oito anos já ajuda tocar uma vaca, um terneiro [...] Na agroindústria trabalham minha esposa e do meu irmão, mas pra tirar pasto e cuidar das vacas são cinco. Faz um serviço, termina esse, vai pro outro e vai, porque nós se envolvemos em várias coisas. Cada um destrincha o serviço. (depoimento de Ilário Lago).

Não obstante identificamos também ocorrências esporádicas de contratação nos picos de produção. As pessoas contratadas são, em geral, vizinhos de propriedade, onde muitas dessas famílias trocam dias de trabalho, ou seja, auxiliam-se mutuamente quando o trabalho agropecuário torna-se mais intenso.

Como as atividades são múltiplas e, por vezes, têm que ser desenvolvidas num mesmo período de tempo dos ciclos produtivos torna-se mister recorrer-se ao auxílio de braços extra-familiares. Conforme nos assina- 
la Salete Castelli, produtora familiar de leite pasteurizado com vistas à policultura, "quando é tempo da uva, né, a gente contrata pra ajudá na colheita, na póda".

Pelo contrário, a situação de encurralamento com que muitas famílias se depararam devido ao acirramento das contradições engendradas pelo fenômeno agrário da modernização da agricultura e a disponibilidade de braços, ociosos em virtude do engendramento dessas mesmas contradições do sistema, fizeram da produção artesanal uma alternativa plausível de inclusão através da geração de trabalho e renda.

As relações de trabalho nas agroindústrias artesanais adaptam-se às circunstâncias de cada unidade. É esse caráter polivalente da força de trabalho que assegura, em grande parte, a reprodução da territorialidade do produtor familiar, já que esta insere-se marginalmente sob ótica mercantil.

O(s) território(s) alternativo(s) da produção agroartesanal constitui, para muitas famílias do Sudoeste paranaense, a principal atividade econômica da unidade produtiva. Prezotto afirma que,

No momento em que se discute um novo papel para o meio rural, não mais apenas de atividades exclusivamente agrícolas, mas de pluriatividade, o modelo de agroindustrialização descentralizado de pequeno porte, de característica familiar, é visto como uma das alternativas capaz de impulsionar uma distribuição de renda mais eqüitativa (PREZOTTO, 2002, p. 138).

A atividade simboliza uma forma de resistência do território da produção familiar perante a natureza desterritorializante do capital, maximizada no espaço rural nas últimas décadas, sobretudo. Diversificando e agregando valor ao trabalho agrícola o agroartesanato tem contribuído para o arrefecimento do processo de desterritorialização do homem do campo.

Conforme pesquisa realizada pela EMATER intitulada "Diagnóstico Unidades Agroindustriais" (EMATER/ PR, 2006), de um universo de 54 famílias pesquisadas, $82 \%$ não tiveram nenhum familiar que migrou do campo para residir em centros urbanos desde que iniciaram a atividade agroartesanal; e, dos $18 \%$ cujos membros da família saíram, a principal razão foi para estudar. Ainda $16 \%$ das unidades estudadas tiveram membros da família que se reterritorializaram no campo.

Para nossa demonstração, escolhemos três produtores agroartesanais de Francisco Beltrão, no intuito de apresentarmos elementos importantes inerentes à reprodução do tempo lento e da lógica de produção familiar. Constituem famílias com dinâmicas territoriais distintas dentre um universo de 31 produtores estudados (conforme mencionado anteriormente). São esses produtores: Gilberto Smaniotto (produtor familiar de leite pasteurizado), Pedro Cuba (produz com sua família filé de tilápia e mel de abelha) e Ivo Matiolo (produtor de açúcar mascavo e melado de cana). As práticas agroartesanais de produção de alimentos ganharam ênfase em Francisco Beltrão/PR na década de 1990 com a criação do Selo de Inspeção Municipal (SIM), adotado em 1996. Em relação ao SIM, Celso Polla, produtor de Mel, destaca que o selo

Ajuda bastante porque tu chega no comércio e tá legal, né. Pode entrar no mercado, pode entrar em qualquer lugar, não tem risco. Eu vejo a dificuldade do pessoal por aí que não tem isso aí. Não tem nem condições de montar isso porque tem um custo, né e começar financiando é a pior coisa que tem.

Salete Castelli, 48 anos, nasceu em Francisco Beltrão, e há 12 anos possui uma agroindústria de pasteurização de leite aos moldes atuais, contudo, registrada somente em 2005 pelo SIM, comenta que: "a gente entregava em litro ${ }^{3}$, daí tivemos que botá a agroindústria porque eles não deixavam mais vender". Vejamos os depoimentos de outros produtores, por nós entrevistados, sobre o Selo de Inspeção Municipal:

É, eu estou com a agroindústria há dois anos, mas trabalho com isso aqui há muitos anos, eu tinha terra, vendi, tinha cinqüenta alqueires, tinha agroindústria lá. Com agroindústria faz vinte anos que eu trabalho (Arthur Ferrari, produtor de derivados de suínos);

A agroindústria registrada tá há uns quinze anos. Trabalhamos também uns cinco anos clandestino. Aquele tempo era bom trabalhar, ganhava dinheiro, não tinha essa burocracia e agora já aperta, né. É embalagem, é fiscalização, é inspetor que vem acompanhar, a gente não pode abater um frango sem a inspeção estar junto (Ambrósio Schmoller, produtor de frango e ovos).

Sempre fizemos queijo, mas não tinha esse negócio de agroindústria, de inspeção neh. Sempre foi feito queijo nesse sistema ali só que era feito queijo dentro de casa assim, era tudo mais artesanal, mais diferente neh. Daí foi falado que tinha que ser diferente, foi feito essa casinha (Ilário Lago, produtor de queijos);

O conhecimento de fabricar cachaça é do tempo passado. De todas as familias, quem tá produzindo já herdou do pai, do avô (Gerônimo Grezgozeski, produtor de cachaça). destinos.

3 "Entregar em litro" significa a prática da venda em domicílio do leite sem o registro da vigilância sanitária: são os chamados clan- 
Devido ao caráter artesanal da produção, menos da metade das unidades estudadas em Eduardo (2008) conseguiram obter o registro do SIM no mesmo ano em que "começaram" a atividade. As adequações foram muitas para que as unidades com registro pudessem comercializar seus produtos a partir da fiscalização efetivada pela Prefeitura Municipal. Algumas dessas unidades permanecem, até o momento, sem qualquer tipo de selo de inspeção. Como são pequenas atividades produtivas, tradicionais e com função originária de subsistência familiar, alguns parâmetros de adequação, quando realizados ocorrem lentamente.

Ao mesmo tempo, a busca por maior autonomia da unidade produtiva familiar, cuja produção seja mais valorizada no mercado, livre da ação de intermediários e das agroindústrias integradoras, são fortes elementos influenciadores ao crescimento dessa atividade no Município de Francisco Beltrão (PR). Confiramos o depoimento de Adelmar Crestani, produtor familiar de leite pasteurizado:

Meu pai morava em outra propriedade, aqui perto, e o trabalho da propriedade era baseado em cima de criação de suínos. Então, eu me criei dentro disso, fazendo parto de porcas, criando os animais, fazendo trato, fazendo a alimentação toda. Quando que saí da casa do pai, que vim pra cá montar a propriedade, também pensava nisso, que era pra vir pra cá pra trabalhar em cima do porco. Logo começou as crises. Porque antigamente era assim: trabalhava durante os doze meses do ano, trabalhava oito meses ganhando dinheiro e quatro não, quatro se empatava com os porcos. Essa coisa começou a apertar de vagarinho, passou de seis em seis meses, seis meses você ganhava, seis meses empatava ou perdia. Tinha lá dois meses, três meses que acabava perdendo, trabalhando no vermelho. E essa questão veio diminuindo mais ainda, veio pra dois meses você ganhando dinheiro, oito meses você empatando, dois meses você perdia. Isso faz vinte anos, que começou essa crise. E eu comecei acompanhar isso, vendo bem de perto e tal que a questão tava começando a apertar. Aí, desse momento, eu virei feirante. Trabalhando, montei umas pequenas estufas e comecei tipo, desisti do porco e tinha que ter um ganho. Fui pra feira e trabalhava como feirante trabalhava na lavoura, na produtividade da lavoura, e da feira, na época, agüentava digamos assim, o mercado, a compra de roupa, e assim por diante que fomos criando os filhos. Depois, mais tarde, comecei com as primeiras vacas. Já tinha algumas vacas antes, mas comecei a virar a propriedade para produzir leite e vender leite pra leiteiro. Foi aumentando a produção de leite e pra chegar onde que eu to hoje teve um longo caminho. Então, os animais que você vê na minha propriedade não foram comprados fora, decerto alguns, muito poucos, todos eles foram criados e adaptados aqui, eu não quis investimentos altos em cima disso. E, com a crise do porco, depois com a passagem da feira, quando foi que comecei a levar leite para algumas casas, já que a gente ia pra cidade começamos a levar leite pra algumas casas, que a gente começou a trabalhar no sistema de agroindústria mais tarde. Depois, desistimos, mais tarde, com a feira e voltamos a trabalhar diretamente com a agroindústria e com a produção leiteira.

Como podemos observar através desse depoimento, a produção agroartesanal tem forte conotação de resistência; no sentido do exercício de uma territorialidade específica, preservando, na gestão de seus territórios sinais de autonomia. Fugindo das privações impostas pelo agronegócio do suíno, a família Crestani optou pelo modelo do agroartesanato.

No caso de Adelmar Crestani, o apelo à produção agroartesanal do leite baseou-se numa forma de contornar as estreitezas político-econômicas impostas a sua família no embate com o agronegócio do suíno. Nesse sentido, o território é elemento essencial para compreendermos a permanência dessas formas específicas de produção: afigura-se como uma possibilidade do exercício do poder (do campesinato, do agronegócio), da autonomia ou da subserviência.

O agroartesanato rural beltronense divide-se em três grupos: a) um grupo, cuja atividade agroartesanal é complementar à dinâmica da unidade agropecuária familiar, em diferentes graus de importância econômica em face de outras atividades agropecuárias (produção de aves, leite, soja, milho, fumo, policultura etc.); b) outro grupo de produtores faz da atividade agroartesanal a principal fonte de renda da unidade familiar; nesse grupo os produtores procuram aproveitar a máxima potencialidade da unidade produtiva para o atendimento das demandas da agroindústria: maior especialização e inserção mercantil nota-se neste grupo; e, c) um último grupo de produtores são os chamados absenteístas: residem no perímetro urbano beltronense desenvolvendo ou não o agroartesanato paralelo a outras ocupações urbanas.

A família Cuba, uma das que destacamos neste texto, é referência no que concerne à prática da policultura (comercial e de subsistência). Além das duas unidades agroartesanais (filetagem de pescados e beneficiamento de mel), produzem uma variedade significativa de produtos. A produção das duas agroindústrias e demais produções variadas (policultura) além de garantir a demanda familiar de alimentos, são comercializadas na feira-livre municipal e constituem a base econômica da unidade produtiva familiar da família Cuba. 
Pedro Cuba, dono de uma agroindústria de beneficiamento de mel, e outra de filetagem de peixes, tem 52 anos e uma propriedade de 15,5 hectares situada nas proximidades da PR 483 - interior do município de Francisco Beltrão/PR, onde reside há 52 anos. É descendente de poloneses oriundos de São Mateus do Sul/PR. Possui o Ensino Fundamental incompleto. Toda a extensão de sua propriedade é aproveitada economicamente, sendo ela composta por: reserva de mata nativa, pomar, açudes (12 tanques) e lavouras (milho, arroz, feijão, erva mate, cana-de-açúcar, verduras, soja, entre outras culturas). Sua família compõe-se de quatro pessoas (três do sexo masculino e uma do feminino), e todos trabalham na agroindústria. Não há contratação de funcionários na unidade produtiva. A assistência técnica, segundo Cuba, prestada pela EMATER e Prefeitura Municipal, resume-se à fiscalização. Como incentivo financeiro recebeu um pequeno financiamento pelo PRONAF (Programa Nacional de Fortalecimento da Agricultura Familiar). As duas agroindústrias artesanais (filetagem de peixes e beneficiamento de mel) constituem as principais fontes de renda da unidade produtiva familiar. Ambas as agroindústrias obtiveram o Selo de Inspeção Municipal no ano de 2000, contudo, as atividades relacionadas à piscicultura e ao mel já eram realizadas pela família há mais de vinte anos.

Em 2006, produziram 200 caixas, oscilando a produção em torno de 25 quilos de mel por caixa anualmente. A família beneficia um total de 5 toneladas de mel por ano, destas, 600 quilos são produzidos no interior da unidade produtiva e o restante é adquirido de outras dez propriedades sob locação ${ }^{4}$. A margem de ganho gira em torno de $50 \%$. Do produto final $80 \%$ é vendido na feira-livre de Francisco Beltrão e $20 \%$ nos mercados locais: Centro de Comercialização da Agricultura Familiar, supermercado Ítalo, Canei frutas. A renda líquida anual da agroindústria de beneficiamento de mel é de $\mathrm{R} \$ 15.000,00$ aproximadamente. As instalações da agroindústria, de propriedade da família, são de alvenaria, medindo $03 \times 04 \mathrm{~m}$. Os instrumentos de trabalho são de propriedade da família e consistem em: mesa inox, pia e centrífuga. A principal dificuldade enfrentada é quanto à atuação dos concorrentes clandestinos e quanto à falta de produto no período do inverno, isto é, quando o mel produzido não pode ser coletado, pois serve como alimento para as abelhas. Outra atividade econômica na propriedade da família Cuba é a piscicultura: venda de peixes via pesque-pague ${ }^{5}$ e através da produção agroartesanal de filés de peixe. Com 12 tanques de peixes, além de subsidiar toda a atividade comercial, envolvendo a prática do lazer através da pesca direta, produz-se matéria-prima $(350 \mathrm{Kg} / \mathrm{mês}$ de tilápia in natura) que é transformada num total de 150 $\mathrm{Kg} / \mathrm{mês}$ de filé de tilápia (peixe de 500 gramas), produto este comercializado na feira de Francisco Beltrão e nos supermercados locais com uma margem de lucro de $40 \%$. Além de complemento semanal à renda da família, a prática do beneficiamento do produto in natura agrega mais valor à mercadoria. Porém, mais de $70 \%$ da produção de peixes é vendida na própria unidade produtiva através do pesque-pague.

Na feira-livre municipal onde há 03 anos a família Cuba comercializa seus produtos pudemos ter uma noção da prática de policultura empreendida pela família. Em um ponto de venda na feira-livre identificamos vários produtos como pomada de pólen, tempero caseiro, filé de tilápia, feijão, arroz, linhaça, tomate, soja, lentilha, cebola, suco de uva, vinho, vinagre, brócolis, trigo, açúcar mascavo, milho, canjica, pipoca, canela, mel, quirera, melado, couve, repolho, couve-flor, batata-doce, laranja, beterraba, abobrinha, entre outros hortifrutigranjeiros produzidos pela família.

A organização produtiva da família Matiolo, produtores artesanais de melado e açúcar mascavo, também ajuda-nos a entender as peculiaridades de uma unidade de produção familiar com elevado grau de diversificação produtiva. A produção artesanal de derivados de cana-de-açúcar tem caráter secundário na orientação econômica da unidade produtiva dessa família; sua principal atividade econômica é a produção de hortifrutigranjeiros vendidos a domicílio, portanto, trata-se de uma unidade que tem como característica a policultura de subsistência e que esta adquire característica comercial.

Ivo Matiolo, descendente de italianos e alemães, possui o Ensino Médio incompleto. É dono e reside numa propriedade de 07 alqueires (aproximadamente 15 ha.), há 34 anos, situada na "comunidade" do Divisor

4 A unidade produtiva que possui potencialidade para as abelhas fabricarem o mel tem o local cedido, pelo dono da propriedade, para o Sr. Cuba. Este, deixando suas caixas de abelha na propriedade fornece uma porcentagem da produção ao proprietário da terra, em torno de $15 \%$

5 A prática do pesque-pague consiste na pesca, in loco, do peixe pelo consumidor. Pescam-se os peixes e estes são pesados e o preço calculado, variando conforme o tipo de peixe (tilápia - R \$ 5,00 por kg; Pacu - R \$ 8,00 por kg). Posteriormente, os pescados são preparados pela família Cuba em ambiente apropriado na própria unidade. O pesque-pague é mais uma fonte de renda da família, pois, durante os momentos de lazer promovidos pela pesca, os visitantes costumam jogar bilhar, consumir bebidas e alimentos que são comercializados em um pequeno bar construído próximo aos locais de pesca. 
- interior do município de Francisco Beltrão/PR. Produz, artesanalmente, açúcar mascavo e melado de canade-açúcar; aproveita economicamente sua propriedade cultivando milho, verduras, cana-de-açúcar (culturas com inserção mercantil), feijão, arroz, mandioca; cria galinhas, suínos etc. (produções de subsistência), e, ainda destina parte de sua propriedade como reserva e potreiro (pastagens).

A família possui também 10 vacas que produzem um total de 70 litros de leite/dia. Produto este vendido para o laticínio Latco de Francisco Beltrão/PR. Sua família é composta por seis pessoas (três do sexo masculino e três do sexo feminino), sendo que quatro trabalham na atividade agroartesanal. A produção total da atividade artesanal de melado e açúcar mascavo é de 02 toneladas mensais; sendo a proporção constituída,

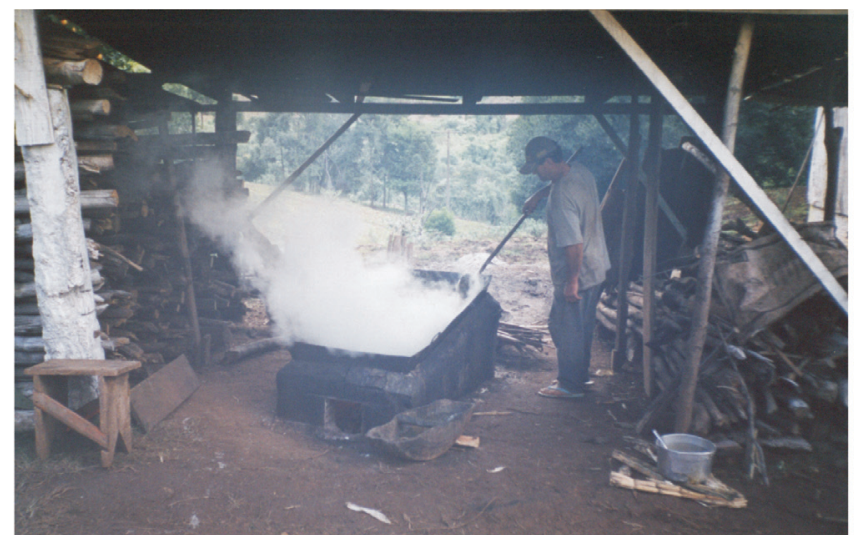

FOTO 1 - Ivo Matiolo fazendo o açúcar mascavo. Em destaque, o tacho artesanal aquecido a lenha. O melado, que depois de "apurado" transforma-se em açúcar mascavo é mexido com uma pá artesanal adaptada.

FONTE: trabalho de campo realizado em 2006.

A renda bruta proveniente da produção agroartesanal é de aproximadamente 05 salários mínimos mensais, porém, a renda líquida total da família está indissociavelmente correlacionada à exploração da dinâmica econômica do conjunto das atividades realizadas na propriedade. O preço do produto é estipulado abaixo do preço médio do mercado, sem prévia elaboração de uma planilha de custos. Segundo Matiolo, um aspecto positivo da produção agroartesanal e da venda de hortifrutigranjeiros a domicílio é a possibilidade da obtenção de dinheiro semanalmente. Em sua propriedade, não se utiliza a prática de contratação de força de trabalho no processo produtivo, contudo, admite a cooperação mútua entre os vizinhos da mesma "comunidade":

Aqui nós trocamos serviço, quando a gente precisa os vizinhos vêm ajudar, quando eles precisam, nós vamos ajudar. basicamente, por $80 \%$ de açúcar mascavo e $20 \%$ de melado de cana. Toda matéria-prima é oriunda de sua propriedade (39 toneladas de cana-de-açúcar ou 11.600 litros de garapa de cana). Utilizam como instrumentos de trabalho um engenho a motor e um tacho, ambos de propriedade da família.

A prática da transformação da cana-de-açúcar é extremamente artesanal e rudimentar. $\mathrm{O}$ tacho (recipiente utilizado no beneficiamento do produto) tem uma medida de aproximadamente $0,60 \times 1,80 \mathrm{~m}$, armazena cerca de 200 litros de garapa (caldo de cana) e é aquecido a lenha (extraída da propriedade). A medida de um tacho de garapa produz $34 \mathrm{~kg}$ de açúcar ou 40 $\mathrm{kg}$ de melado, sendo o tempo médio para o fabrico do melado de quatro horas e a do açúcar mascavo de seis horas.

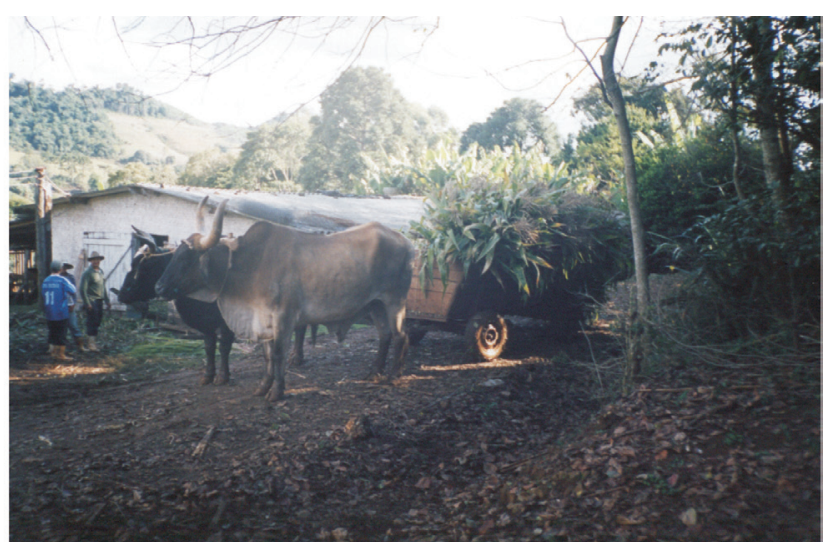

FOTO 2 - "Carreta", meio de transporte artesanal utilizado em diversas tarefas da família Matiolo. Ao fundo, vizinhos de propriedade auxiliam na silagem do milho, uma prática de auxílio mútuo muito difundida em territórios da agricultura familiar.

A principal dificuldade enfrentada é quanto ao mau estado de conservação da estrada que liga sua propriedade com a rodovia que concede acesso a Francisco Beltrão (trecho de aproximadamente $4 \mathrm{Km}$ ). Por tratar-se de uma atividade complementar, o agroartesanato efetivado pela família Matiolo tem no equipamento rústico e nas técnicas tradicionais de produção seu foco, o que é expresso nos códigos de territorialidade familiar.

Gilberto Smaniotto é descendente de italianos, cujo pai residia em Araquiba/RS. Smaniotto era agricultor no Rio Grande do Sul, mas foi desapropriado porque suas terras foram alagadas pela barragem de Itá. Possui o Ensino Médio completo. É dono e reside em uma propriedade de 18,4 hectares desde 1988. Sua agroindústria está localizada na Cabeceira Rio do Mato, município de Francisco Beltrão/PR. 
Complementando a atividade agroartesanal, cultiva 10 hectares de milho, 3 de soja e 5,4 de pastagens. Sua família é composta por seis pessoas (quatro do sexo masculino e duas do sexo feminino) e todos trabalham na agroindústria, em média, 10 horas/dia e 31 dias/mês. Segundo Gilberto Smaniotto, a assistência técnica tem sido efetivada de maneira particular. Tanto a EMATER quanto a Prefeitura Municipal vêm atuando apenas no sentido de fiscalizar e promover avaliações sobre a produção. O ganho líquido aproximado da atividade agroartesanal é de 05 salários mínimos mensais.

A agroindústria foi construída há 10 anos e, a partir de sua instalação, o manejo da unidade produtiva familiar passou a ser orientado em torno dessa atividade, no sentido de prover as matérias-primas necessárias ao processo produtivo. A principal dificuldade enfrentada é quanto à atuação de clandestinos no mercado e quanto à inadimplência por parte de alguns clientes.

Em 2004, a família Smaniotto comercializava sua produção em quatro creches do município e entregava o restante da produção diretamente ao consumidor. A agroindústria pasteurizava um total de 7.000 litros $/ \mathrm{mês,}$ sendo $1.500(21,5 \%)$ litros adquiridos de outros produtores de sua localidade e o restante $(78,5 \%$ ou 5.500 litros) eram provenientes de sua propriedade.

Em 2007, voltamos a visitar a propriedade. O processo de produção estava improvisado na garagem do domicílio da família, pois a agroindústria estava passando por reformas. Em 2006, a família perdeu a autorização para comercializar seu produto nas quatro creches às quais atendia, devido a uma suposta inadequação tecnológica de sua agroindústria perante a exigência do governo do Estado do Paraná. Por isso, está tentando readequar sua agroindústria, investindo um total de $\mathrm{R} \$ 50.000,00$ em equipamentos e estrutura física no intuito de conseguir novamente a licitação das creches de Francisco Beltrão.

Em 2005, construíram também um aviário para a criação de perus, sob sistema de integração à Sadia (o investimento total foi de $\mathrm{R} \$ 90.000,00$, sendo $50 \%$ de recursos próprios), visando aproveitar o esterco gerado para adubar sua propriedade:

Há oito anos que nós tem as vacas na terra, né, e a terra estava meio morta. Pra comprar cama de aviário pra recuperar a terra fica muito caro, né. Daí é uma atividade a mais e a gente pensa que com o adubo vai voltar pro leite, né (depoimento de Gilberto Smaniotto).

Sobre o sistema de integração, o produtor des- taca que:

\begin{abstract}
Alojamos cinco lotes aqui no aviário. Vai dizer o que da Sadia? Ela te traz os peruzinhos, te traz a ração, vem o veterinário uma vez por semana, eles carregam os perus, levam e tu não sabe nada. Eu acho que o aviário não paga o investimento. Quem financia 70\% não paga. Eu financiei metade. Quem pode com uma firma grande? A gente sai sempre perdendo. Daí o dólar despencando e eles alegam que também vendem em dólar daí os preços despenca também. Quando tivemos pensando em colocar o aviário quem tinha aviário e deixava uma média de 60 dias na propriedade dava de 80 a 90 centavos por cabeça; hoje não chega a 40. Ta apertando cada vez mais.
\end{abstract}

A família Smaniotto, mesmo com a construção do aviário não mudou de orientação produtiva. $O$ aviário foi construído para fortalecer a produção familiar. E analisando os depoimentos é possível perceber o nível de esclarecimento que a família tem em relação à dinâmica de exploração do agronegócio.

Ele possui ainda 45 cabeças de gado ( 25 produzindo) holandesas e jersey, melhoradas por inseminação artificial feita pelo próprio Gilberto, que há oito anos possui um botijão de sêmen. Adquire como matéria-prima 2 toneladas de ração por mês $(R \$ 800,00)$ oriunda da Candu (Dois Vizinhos), o restante da matéria prima é da propriedade (silagem, pasto e cana-de-açúcar). Os meios de transporte são próprios: uma caminhonete e um trator. Esporadicamente contratam mão-de-obra no processo produtivo, sem carteira assinada, basicamente quando fazem a chamada "silagem" do milho. A instalação da agroindústria é própria, de alvenaria medindo 04 $x 5,5 \mathrm{~m}$. Os instrumentos de trabalho são de propriedade da família: 3 freezers, embaladeira e pasteurizador de leite, além de outros utensílios domésticos utilizados no processo produtivo. O preço do produto final é estipulado a partir do preço do leite dos Laticínios. O produtor está construindo em sua propriedade uma área de lazer com quiosques e campo de futebol, visando potencializar a prática do turismo para receber clientes.

Smaniotto, ponderando alguns aspectos sobre a reestruturação de sua unidade agroartesanal destaca que:

Esse leite que o Requião dá pras famílias, só hoje, perdi umas sessenta famílias que agora ganham. A EMATER me disse que se eu conseguir equipar a agroindústria do jeito que eles querem é bem fácil que eu consiga embalar o leite das crianças ${ }^{6}$. Porque a preferência é

6 Alusão ao programa governamental instituído pelo Governador Requião "Leite das Crianças". Somente os grandes Laticínios têm vendido leite ao programa devido as inúmeras exigências técnicas requeridas. Várias famílias produtoras agroartesanais perderam sua clientela com a instituição do programa, sendo que, algumas dessas famílias encerraram suas atividades agroartesanais. 
pras agroindústrias e aqui não tem nenhuma capacitada. Quem esta embalando é a Latco. Vamos colocar o CNPJ pra tentar licitação das creches, vamos colocar

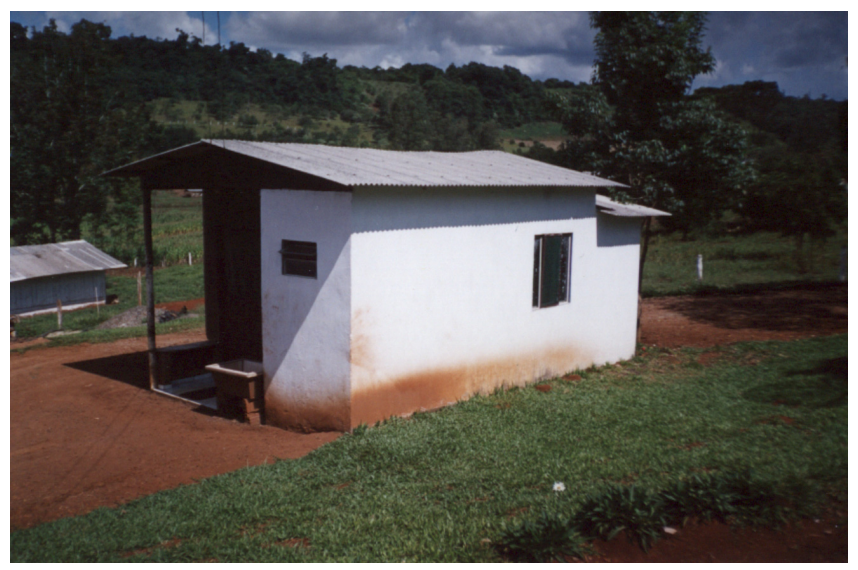

FOTO 3 - AGROINDÚSTRIA DE GILBERTO SMANIOTTO (VISTADA UNIDADE). TRABALHO DE CAMPO REALIZADO EM 2004

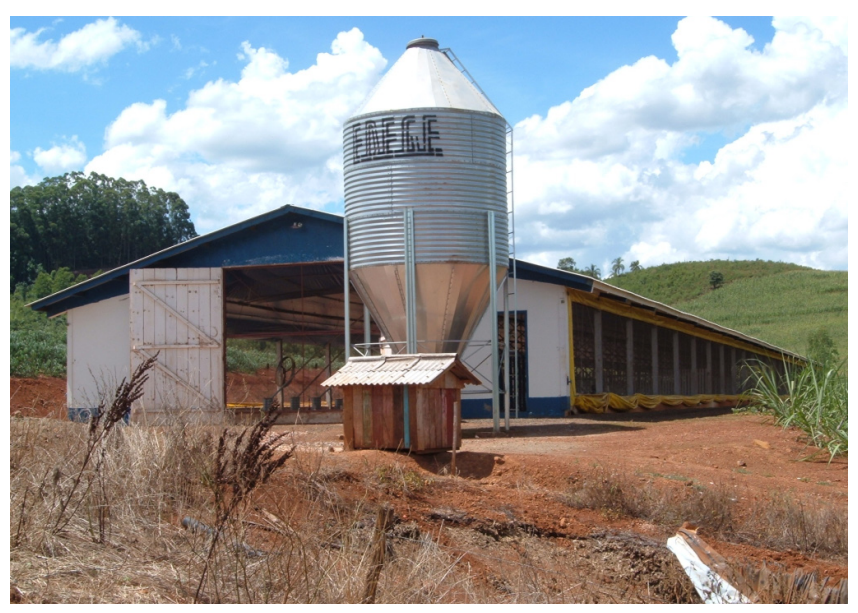

FOTO 5 - AVIÁRIO INTEGRADO À SADIA CONSTRUÍDO EM 2005 NA PROPRIEDADE DE GILBERTO SMANIOTTO

FONTE (fotos 4, 5 e 6): trabalho de campo realizado em 2007.

A grande questão a qual se baseia a disputa territorial para a família Smaniotto consiste na tentativa de modernização da agroindústria familiar. Será que essa família que produz leite com certificação municipal de qualidade do produto não tem condições de inserir-se nesse programa? O Estado, subsidiando o grande capital, circunscreve-se como excludente e fomentador de conflitualidades territoriais. A modernização, nesse caso, não significa capitalização (pode vir a ser?), mas designa, contraditoriamente, resistência. pra funcionar [...] A intenção é colocar lá um resfriador de expansão, um tanque de equilíbrio, pasteurizador de placa, embaladeira, câmara fria, essas coisas tudo (Gilberto Smaniotto).

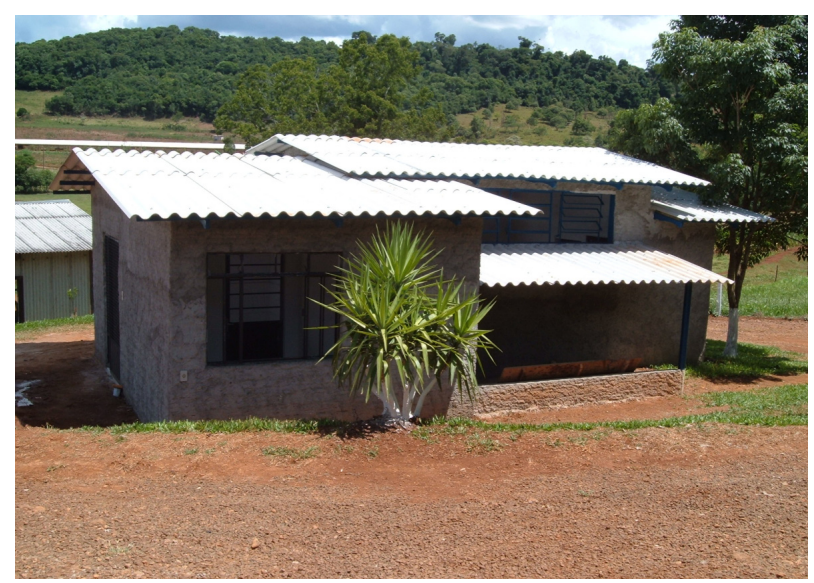

FOTO 4 - AGROINDÚSTRIA DE GILBERTO SMANIOTTO, EM PROCESSO DE AMPLIAÇÃO

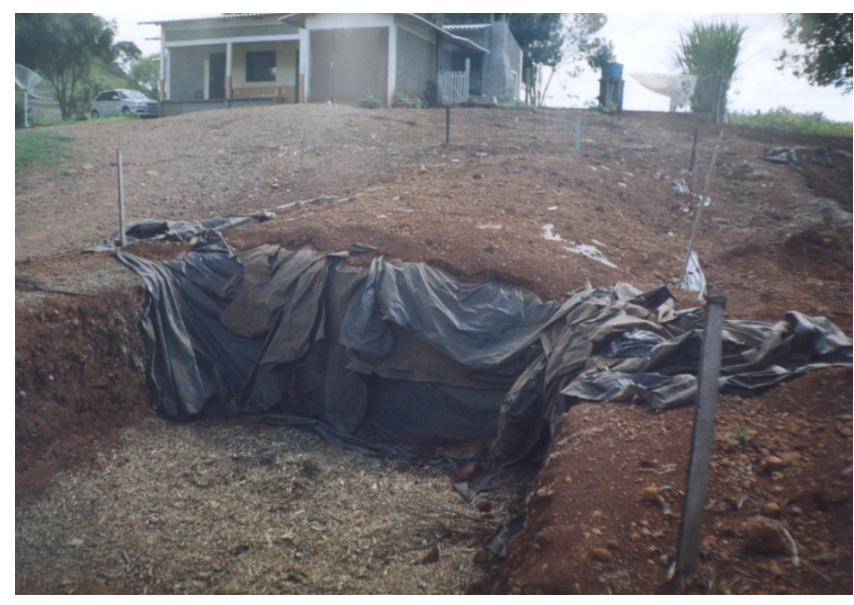

FOTO 6 - PROPRIEDADE DE GILBERTO SMANIOTTO - SILAGEM DO MILHO PARA ALIMENTAR O REBANHO

Dentro do que destacamos anteriormente sobre as diferenciações existentes entre as formas de organização territorial agroartesanal, sua propriedade encaixa-se no grupo de produtores que direcionam as potencialidades da unidade para o atendimento da produção agroartesanal. Com uma ressalva, um mínimo de policultura de subsistência é garantida na unidade:

Farinha vem de lá, feijão vem de lá [do mercado urbano]. De origem animal a gente tem: banha, salame, leite, queijo, mandioca, verdura (Gilberto Smaniotto). 
De maneira geral, a partir do que constatamos em campo o agroartesanato em Francisco Beltrão é caracterizado por pequeníssimas unidades produtivas que atendem uma pequena parcela do mercado local e/ou regional. As técnicas produtivas são bastante rudimentares e o trabalho é basicamente familiar, resultantes da reprodução parcial de conhecimentos e experiências simbólico-identitárias. Em muitas propriedades estudadas, coexistem elementos do território da produção familiar com elementos do território do agronegócio, relações de poder que se sobrepõem, determinando o ritmo de trabalho, de produção e de vida em cada unidade produtiva familiar.

\section{CONSIDERAÇÕES FINAIS}

Se por um lado o capital se apropria do trabalho da família agricultora, os produtores familiares, sob certas circunstâncias, também podem fazer uso de atividades capitalistas sem tornarem-se necessariamente produtores capitalistas. A questão da monopolização do território da agricultura familiar pelo capital pode relativizar-se.

A subordinação adquire caráter relativo e consciente. É o que constatamos em nossas pesquisas sobre o agroartesanato. Juntamente com as atividades artesanais de produção de alimentos, o produtor familiar pode realizar atividades tipicamente capitalistas em sua propriedade, como é o caso da produção de soja e de fumo, e outras atividades vinculadas aos sistemas de integração, como acontece com a criação de aves, de suínos e com a produção de leite. Esta situação é muito normal em Francisco Beltrão, conforme verificamos em campo.

Em momentos de crise desses segmentos produtivos capitalistas (queda do preço do leite e da soja, por exemplo), a família recorre a seus trunfos de gestão do território (policultura, agroartesanato, redes de solidariedade etc.) mantendo sua condição de produtor relativamente independente: por essa razão a consciência política do agricultor familiar diante da natureza desterritorializante do capital, é fator essencial a sua reprodução.

$\mathrm{Na}$ analítica territorial, o reconhecimento das múltiplas atividades e territorialidades remete-nos ao entendimento de que não há uma lei inexorável que assegure a continuidade de um padrão linear de desenvolvimento do capitalismo agrário. Os próprios efeitos de desagregação da agricultura familiar frente ao agronegócio podem se relativizar segundo a dinâmica territorial em cada unidade de produção e ação das políticas públicas.
A opção pela abordagem territorial histórica e relacional facilitou, em nosso entendimento, a compreensão da heterogeneidade presente no espaço rural de Francisco Beltrão. Pudemos evidenciar tanto aspectos da colonização efetiva do Sudoeste do Paraná, da identidade dos migrantes, do saber fazer, do agroartesanato, como da modernização da agricultura e da expansão do capital por meio dos grandes complexos agroindustriais. E isto é fundamental, para que possamos produzir conhecimento desmascarando desigualdades e contradições, ritmos e diferenças, controle e subordinação, e iniciativas que significam sinais de autonomia na prática agrícola familiar.

\section{REFERÊNCIAS}

ABRAMOVAY, Ricardo. Transformações na vida camponesa: o Sudoeste paranaense. Dissertação (Mestrado em Ciências Sociais) - USP. São Paulo, 1981.

Paradigmas do capitalismo agrário em questão. Campinas: Hucitec, ANPOCS, UNICAMP, 1992.

ALENTEJANO, P. R. R. Pluriatividade: uma noção valida para a análise da realidade agrária brasileira? In: TEDESCO, J. C. Agricultura Familiar: Realidades e Perspectivas. 2. ed. Passo Fundo: EDIUPF, 1999.

AMIN, Samir; VERGOPOULOS, Kostas. A questão agrária e o Capitalismo. Tradução de: RESENDE, Beatriz. Rio de Janeiro: Paz e Terra, 1986.

CENNI, Franco. Italianos no Brasil: "andiamo in Mérica". 3. ed. São Paulo: Editora da Universidade de São Paulo, 2003.

CHAYANOV, Alexander. Sobre a teoria dos sistemas econômicos não-capitalistas. In: SILVA, José Graziano; STOLCKE, Verena (Orgs.). A Questão Agrária. São Paulo: Brasiliense, 1981.

DEMATTEIS, Giuseppe. Sistema Local Territorial (SLOT): um instrumento para repensar, ler e transformar o território. In: ALVES, A.; CANDIOTTO, L.; CORRIJO, B. (Org.). Desenvolvimento Territorial e Agroecologia. São Paulo: Expressão Popular, 2008.

DUARTE, Valdir P.; GRIGOLO, Serinei C. (Org.). Agroindústria Associativa/Familiar: o mito da viabilidade. Francisco Beltrão: ADMR, 2006.

EDUARDO, Márcio Freitas. A dinâmica territorial das agroindústrias artesanais de Francisco Beltrão/PR .Dissertação (Mestrado em Geografia) - Programa de pós-graduação em geografia/UNESP, Presidente Prudente, 2008.

FERES, João Bosco. Propriedade da Terra: opressão e miséria. Amsterdam: Latin American Researcli, 56. s/d. 
EDUARDO, M. F.; SAQUET, M. A. Elementos do ritmo lento da territorialização do...

FERNANDES, Bernardo M. Sobre a Tipologia dos Territórios. In: SAQUET, M.; SPOSITO, E. (Org.). Territórios e territorialidades: teorias, processos e conflitos. São Paulo: Expressão Popular, 2009.

HAESBAERT, Rogério. Des-territorialização e identidade: a rede "gaúcha" no Nordeste. Niterói: EdUFF, 1997.

Territórios Alternativos. Niterói/RJ: São Paulo: Contexto, 2002.

IANNI, Octavio. Estado e Capitalismo. São Paulo: Brasiliense, 1989.

INSTITUTO BRASILEIRO DE GEOGRAFIA E ESTATÍSTICA. (IBGE). Censo agropecuário. Rio de Janeiro: Ed. IBGE (vários anos).

anos).

Censo demográfico. Rio de Janeiro: Ed. IBGE (vários

INSTITUTO PARANAENSE DE ASSISTÊNCIA TÉCNICA E EXTENSÃO RURAL (EMATER). Diagnósticos unidades agroindustriais: região grande fronteira do mercosul. Francisco Beltrão: EMATER, 2006.

KALNIN, Joanir L. Desenvolvimento local/regional focado na agroindústria familiar: experiências em Santa Catarina. Tese (Doutorado em Engenharia de Produção) - UFSC, Florianópolis, 2004.

KAUTSKY, Karl. A questão agrária. São Paulo: Abril Cultural, 1986.

LAZIER, Hermógenes. Análise histórica da posse da terra no Sudoeste paranaense. Curitiba, 1997.

LEFEBVRE, Henri. Lógica formal. Lógica dialética. Rio de Janeiro: Civilização Brasileira, 1983. (Coleção perspectivas do homem; v. 100).

LÊNIN, Vladimir llich. O desenvolvimento do capitalismo na Rússia. O processo de formação de mercado interno para a grande indústria. Tradução de: NETTO, José P. São Paulo: Abril Cultural, 1982.

Capitalismo e agricultura nos Estados Unidos da América: novos dados sobre as leis de desenvolvimento do capitalismo na agricultura. São Paulo: Brasil Debates, 1980.

MAIA, Antônio C. Sobre a analítica do poder de Foucault. Tempo Social, Revista de Sociologia da USP, São Paulo, v. 7, n.1/2, p. 83-103, out. 1995.

MARIOT, Edson João. Produtos agroalimentares típicos (coloniais): situação e perspectivas de valorização no município de Urussanga, Santa Catarina, Brasil. Dissertação (Mestrado em Gestão do Desenvolvimento Rural) - Universidade de Trás-os-Montes e Alto Douro/Universidade de Santiago de Compostela, Vila Real, 2002.

MARTINS, José de Souza. O poder do atraso: Ensaios de Sociologia da História Lenta. São Paulo: Hucitec, 1994.
. O cativeiro da terra. São Paulo: Hucitec, 1990.

MARX, Karl. O Capital. Livro 1, Volume 2. Rio de Janeiro: Bertrand Brasil, 2002.

NEVES, Delma. P. Diferenciação sócio-econômica do campesinato. Revista Ciências Sociais Hoje, p. 220-241, 1985.

OLIVEIRA, Ariovaldo Umbelino de. A Agricultura Camponesa no Brasil. 4. ed. São Paulo: Contexto, 2001.

PREFEITURA MUNICIPAL DE FRANCISCO BELTRÃO Estatísticas Industriais e agroindustriais. Francisco Beltrão, 2004.

PREZOTTO, L. L. Uma concepção de agroindústria rural de pequeno porte. Revista de Ciências Humanas da UFSC, p. 133-153, 2002.

RAFFESTIN, Claude. Por uma geografia do Poder. São Paulo: Ática, 1993.

ROCHE, Jean. A colonização alemã e o Rio Grande do Sul. Tradução de: RUAS, Emery. Porto Alegre: Editora Globo, 1969.

RUSSELL, Bertrand. O poder: uma análise social. Lisboa: Editora Fragmentos, 1990.

SACK, Robert. Human territoriality: its theory and history. Cambridge: Cambridge University Press, 1986.

SANTOS, Milton et al. Território. Globalização e fragmentação. São Paulo: Hucitec/ANPUR, 1994.

. Fim de século e globalização. São Paulo: Hucitec/ ANPUR, 1993.

SANTOS, Milton. Técnica, espaço, tempo: Globalização e meio técnico-científico informacional. São Paulo: Hucitec, 1997.

SANTOS, Roseli Alves. O processo de modernização da agricultura no Sudoeste do Paraná. Tese (Doutorado em Geografia). Programa de pós-graduação em geografia/ UNESP, Presidente Prudente, 2008.

SAQUET, Marcos A. Os tempos e os territórios da colonização italiana. Porto Alegre: EST Edições, 2003.

SHANIN, Teodor. Lições Camponesas. In: PAULINO, E.; FABRINI. J. (Org.). Campesinatos e Territórios em Disputa. São Paulo: Expressão Popular, 2008.

WACHOWICZ, Ruy. Paraná, Sudoeste: ocupação e colonização. Curitiba: Ed. Literotecnica, 1985. 